\title{
Solving the Century Problem "Modern Transformation of China’s Traditional Confucianism”-A Mistake-Tolerant Democracy Perspective
}

\author{
ZHOU Zhifa \\ Zhejiang Normal University, Jinhua, China
}

\begin{abstract}
The reason why Chinese scholars cannot bridge between Confucianism and democracy as a century problem since 1920s is that liberal democracy has two fundamental defects: Human beings born with wisdom have known rights before entering societies, which is contrary to Confucianism; separation between politics and religions has led to religious ceremony of confession far away from politics. Mistake-tolerant democracy whose right theory is the right to trial and error as an original right and mutual empowerment theory can overcome above defects. Liberty is divided into the right to trial and error as an original right in innovative fields which can be transferred by contract and unalienable liberties in non-innovative ones. The spirit and behavior of self-criticism to people like confession is a virtue which meets Confucian moral requirements of becoming a Saint and politician's obligation required in mistake-tolerant democracy, which can solve the century problem at utmost.
\end{abstract}

Keywords: Confucianism, Neo-Confucians, right to trial and error, mutual empowerment theory, mistake-tolerant democracy, liberal democracy

\section{Introduction: Dilemma of Modern Neo-Confucianism}

Confucianism initiated by Confucius has been confronted with two greatest cultural challenges in the history of Chinese civilization for over 2,500 years. Buddhism is the first one. After the collapse of Han Dynasty, Confucianism declined. Metaphysics flourished during the period of Wei and Jin Dynasties (220-420 AD), and Buddhism dominated in Northern and Southern Dynasties (420-589 AD) and Sui and Tang Dynasties (581-907 AD). Until Song Dynasty (960-1279 AD), scholars such as Cheng Hao, Zhu Xi, and Lu Jiuyuan etc., as representatives of Neo-Confucians, absorbed thoughts of Buddhism and Taoism, and created moral Confucianism of Confucius and Mencius as Neo-Confucianism, and made it mainstream culture. It took more than 800 years for Confucianism to re-emerge from its decline in the late Han Dynasty to domination in Song Dynasty by its integration with Buddhism. The second one is that Western value of democracy and science has threatened the existence of Confucianism in modern societies, unless China's scholars can find a bridge to connect moral Confucianism with Mr. Democracy and Mr. Science. Since the Opium War in 1840, China has experienced violent and extreme changes. Confucianism as the core ideology of feudal dynasties was

Acknowledgement: I really appreciate my colleague, Associate Professor Yaxiong ZHU who helped me revise grammatical problems in the article.

ZHOU Zhifa, Associate Professor, Institute of African Studies, Zhejiang Normal University, Jinhua, China. 
confronted with impacts and challenges far beyond the threat of Buddhism. It is well known that Western countries, before its values came to China, had experienced a reflection of the Middle Ages, Renaissance, Enlightenment, Industrial Revolution, democratic practices, and maturity of liberalism as ideology, and all over the world cannot avoid the influence of Western values of democracy and science.

In order to deal with the greatest change which never happened in the past 3,000 years of China, Zhang Zhidong, a famous Viceroy in the late Qing Dynasty, suggested that Qing Dynasty keep the core value of doctrines of Confucian and Mencius, and learn Western science and method for practical purposes. He attempted to maintain Confucianism as official ideology and reject Western political value (Zhang, 1900). Kang Youwei spread Western ideas in the name of their predecessors at the expense of distorting history. According to his opinion, the old bottle of Confucius's ideas has included new wine, equality, and democracy (Tang, 1981). When Confucianism totally lost its support of traditional feudal political system and soil of practice, it moved from center to edge. Especially since May Fourth Movement in 1919, Confucianism had to bear more violent criticism and doubt. The core value of Confucianism, "Benevolent love, righteousness, propriety, wisdom, and faithfulness", has largely lost its right to speech under the impact of Western culture, especially the Enlightenment value of "Freedom, Equality, Fraternity, and Human Rights”. To recover Chinese confidence in traditional culture, China's intellectuals, such as Liang Shuming, Xiong Shili, Mou Zongsan, Tang Junyi, Xu Fuguan, and Zhang Junmai did their utmost to find out the future of traditional Confucianism, and developed new theories called modern Neo-Confucianism. Their main tasks are to realize modern transformation of traditional Confucianism, which means that they are seeking to build a bridge between moral Confucianism and "Mr. Democracy and Mr. Science". This problem concerns the future of Chinese civilization and politics, or even it is related to the trend of the whole Eastern Asian Confucian cultural circles (He, 2001, p. 1).

The problem of modern transformation of traditional Confucianism can be divided into three sub-problems: (1) How can we preserve and develop moral Confucianism in modern society? (2) How can we build a bridge between moral Confucianism and Mr. Science? (3) How can we build a bridge between moral Confucianism and Mr. Democracy? Since May Fourth Movement that highlighted the importance of Mr. Democracy and Mr. Science, none of modern Confucians have solved sub-problem 2 and 3. For sub-problem 1, Liang Shuming as a pioneer of modern Neo-Confucians developed moral Confucianism inspired by Buddist philosophy and Bergson's life philosophy (Liang, 1999). He once said to his disciples, "I feel that I have a great responsibility to give an account of Chinese Confucianism and an opportunity to connect it with modern academics” (Liang, 1989, p. 136). Xiong Shili constructed the philosophy of identity of forms and their function (Ti Yong Bu Er) inspired by Yogachara Buddhism (Xiong, 1985; Song, 2007). Mou Zongsan and Tang Junyi etc. have integrated Neo-Confucianism with Western philosophy in order to make Neo-Confucianism with modern characteristic (Mou, 2006; Tang, 2005). In Liang's opinion, it is very difficult for China to reach Western democratization, because Western democratic politics could not be compatible with China's traditional culture that attempts to harmonize itself and uphold the doctrine of the Mean as its fundamental spirit, instead of Western culture which concentrates the desire to advance as its basic principle (Liang, 1999, pp. 61-63). Liang's judgement has shown how difficult it is for sub-problem 2 and 3 to be solved. On the other hand, Liang Shuming's concept of democracy was influenced by Deweyan democracy, but he placed much more emphasis on the ethical meaning of democracy than Deweyan democracy (Gu, 2018). Mou Zongsan summarized the mission of modern Neo-Confucians and put forward "unification of three traditions": (1) to affirm Confucian 
value of "Tradition of Dao" or "Tradition of Morality”. "Tradition of Morality” belongs to the doctrine of Inner Sageliness that means the talent and morality of a Saint; (2) to develop science and technology as Outer Kingliness from morality Confucianism, which is called "Tradition of Learning"; (3) to develop democracy as Outer Kingliness supported by morality Confucianism, which is called "Tradition of Politics” (Mou, 2010). Mou Zongsan's “unification of three traditions” corresponds to the above three sub-problems respectively.

Most modern Neo-Confucians believe that there is no essential paradox between traditional Confucianism and "democracy and science". Confucianism has the original genetics of modern democracy, but failed to grow up in the feudal history. In 1958, representatives of modern Neo-Confucianism, Mou Zongsan, Xu Fuguan, Zhang Junmai, and Tang Junyi, published a joint declaration entitled "A Manifesto on the Reappraisal of Chinese Culture: Our Joint Understanding of the Sinological Study Relating to World Cultural Outlook” (Zhang, 2006), marking the formation of modern Neo-Confucianism in Hong Kong and Taiwan. In the 1970s and 1980s, under the direct influence of modern Neo-Confucianism in Hong Kong and Taiwan, a number of large-scale “overseas Neo-Confucians”, such as Yu Yingshi, Du Weiming, Liu Shuxian, and Cheng Zhongying, emerged. Yu Yingshi highlighted the development of Confucianism lay in daily life of human beings (Yu, 1998, pp. 38-45). Du Weiming has been devoted to the study of innovation of Confucianism, dialogue of civilization, cultural China, reflection on Enlightenment, and other fields, highlighting creative transformation of Confucianism to respond to challenges of Western culture (Du, 2005).

At the beginning of the 21st century, although modern Neo-Confucians attempted to solve sub-problem 2 and 3, by publishing many articles and books, and forming complicated systems of metaphysics which is difficult to dialogue with Western ideas, their achievements are mainly focused on sub-problem 1. Sub-problem 2 and 3 are still unsolved, so modern transformation of traditional Confucianism has been called the century problem for China up to now. Then, is there any solution to it? If there is any, how can Confucianism as a moral theory connect democracy and science naturally? How can we make Chinese people believe that China's modern way can keep traditional morality as fundamental principles to administer our country in the times of industrial civilization? If there is no one, what will happen for China? He Lin thought, "If Chinese people could not keep Confucianism or traditional cultural spirit as her main body when we learn Western values, China would lose her cultural autonomy, and become cultural colony of Western ideology” (He, 1988; Mou, 2006, p. 22). But Ye Renchang put forward a novel and surprising idea,

Since the late Qing Dynasty, Confucianism has borne huge pressure increasingly, and has to demonstrate its own modernity such as democracy and science in order to obtain rationality of existence in modern societies. This is rather a sorrow. Why is it not the other way around that democracy and science has to justify their value and rationality of existence to Confucianism? (Ye, 2005, p. 2)

This is the easiest way to make Chinese culture self-confident promptly indeed, but they have forgotten Confucius's spirit is good at learning, "He (a gentleman) is the kind who can be called a lover of learning" (Waston, 2007, p. 18). Ye Renchang seemingly forgot that if Confucian did not have any relationship to democracy, the only function of it would justify autocracy,

It is unfair for such a vast and rich spiritual tradition to insist that the value of Confucianism and rationality of its existence be measured by whether it contributes to democracy or not. One can say with certainty that even in modern and post-modern times, Confucianism, even not nearly related to democracy, has its place outside democracy. (Ye, 2005, p. 2) 
Actually it is very dangerous for us to escape from our main mission, because no people would like to give up their human rights, which is the core of democracy.

The past 100 years saw many intelligent scholars spending all their lives attempting to solve it, but they have not succeeded. The more time elapses, the more likely Chinese scholars lose their patience and decide to abandon answering it (Guo, 1997). For instance, Song Zhiming stated,

Moral Confucianism did not successfully develop the "new Kingliness without (new Outer Kingliness)" from its "Sageliness within (Inner Sageliness)", respond to modernization marked by science and democracy, and provide moral impetus for the development of a modern Chinese society. (Song, 2007, p. 503)

Song's words nailed the coffin firmly on the fate of Confucianism, because modern Neo-Confucians cannot find any definite clue to achieve the mission up to now. On the contrary, they can illustrate all kinds of negative evidences to deny the possibilities. Ren Jiantao argues that morality should be separated from politics just like the separation between politics and religion in the West, and then completely has denied the necessity of modern transformation of traditional Confucianism, which means sub-problem 2 and 3 do not exist and all the Neo-Confucians wasted their lives for nearly 100 years. So he declared,

Trying to explain how Inner Sageliness (morality) leads directly to Outer Kingliness (democracy and science) is an ancient attitude that refuses to separate politics from morality properly. The stronger such a claim is, the more Confucianism resists modern trend that social elements should be split into different fields. The separation between Inner Sageliness and Outer Kingliness is a social reconstruction problem just like that between politics and religion in Western society. (Ren, 2018, p. 92)

When modern Neo-Confucians have attempted to answer the century problem, they usually regard liberal democracy as absolute truth to criticize defects of traditional Confucianism and reinterpret its virtues fit for modern societies creatively. However, during the development of modern Neo-Confucianism, scholars seldom had an opportunity to doubt the universality of liberal democracy in practice and theory. After Financial Crisis in 2008, however, we may wonder why market economy and liberal democracy as universal value spreading in the world in the past 40 years could not help USA and EU avoid it. Liberal democracy has a strong ability to correct its mistake, but it does not work in reality (Dumenil \& Levy, 2004; Saad-Filho \& Johnson, 2005). To criticize traditional Confucianism with liberal democracy, we need to consider whether liberal democracy is suitable for China with confidence. If it is fit for China, is it necessary to reconcile traditional Confucianism with liberal democracy? And can we create a different democratic theory, such as Confucian democracy (Hall \& Ames, 1999; Chang, 2003; Tan, 2004; Ackerly, 2005; Gu, 2018), even more universal theory of democracy than liberal democracy? Mistake-tolerant democracy proposed in this context regards that it is more universal than liberal democracy, because the state of nature in mistake-tolerant democracy is integrated with the method of trial and error, which makes the former more reliable. The author will show that mistake-tolerant democracy can solve the century problem haunting Chinese academic circle for nearly 100 year since May Fourth Movement in 1919 (Zhou, 2018); i.e., the route from "Inner Sageliness (Moral Confucianism) to Outer Kingliness (Science and Democracy)” should be changed to a new one from "New Outer Kingliness (new democratic theory rather than liberal democracy) to New Inner Sageliness (reconstruction of moral Confucianism based on the new democratic theory)" (Lin, 2001). As shown in Figure 1, there are double reconstruction missions we have to undertake: The first is to reconstruct Western democratic theory. In this article, the new democratic theory is mistake-tolerant democracy introduced in brief; the second is to 
reconstruct moral Confucianism, which is from Outer Kingliness (Mistake-Tolerant Democracy) to Inner Sageliness (New Moral Confucianism).

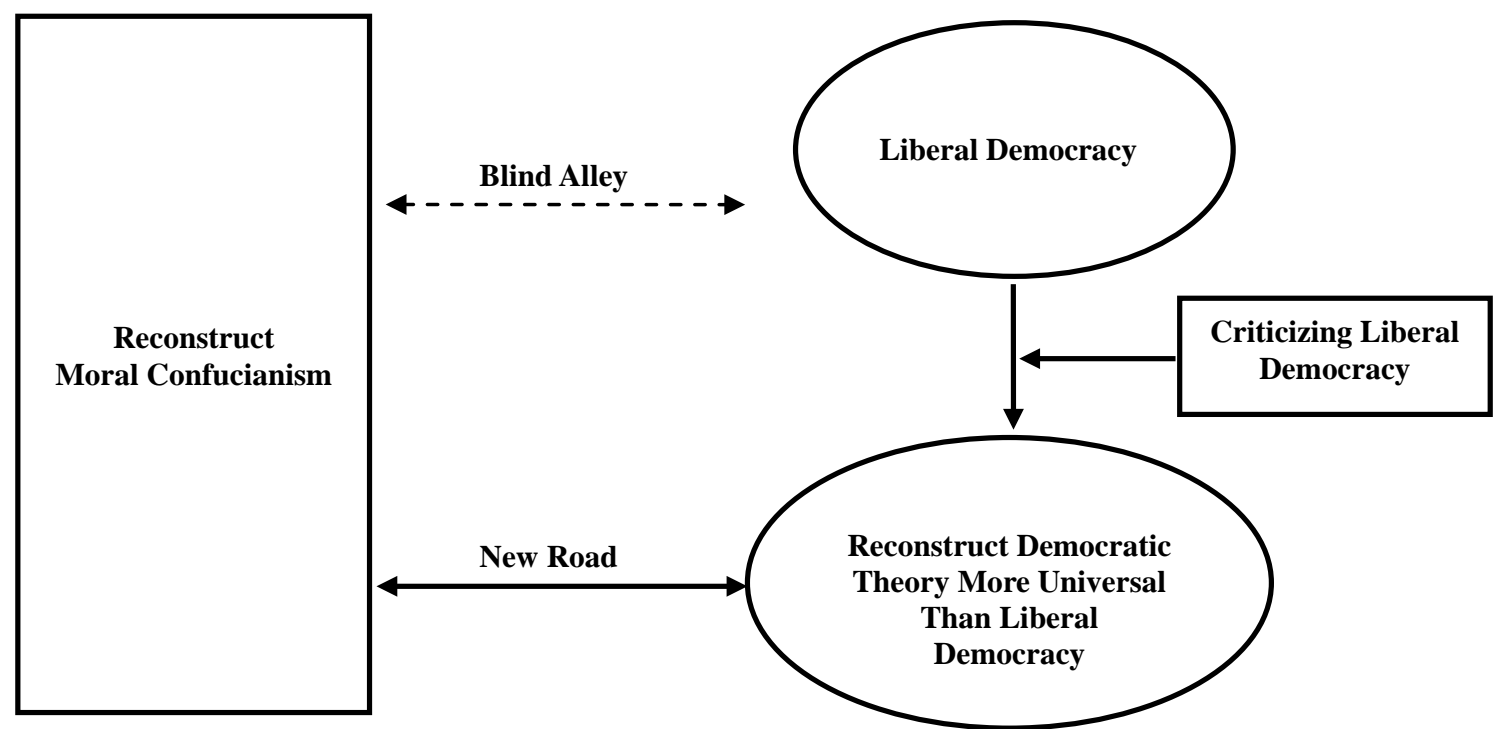

Figure 1. Double missions of modern transformation of traditional Confucianism: Reconstruct Western democratic theory, and then reconstruct moral Confucianism.

\section{Modern Transformation of Traditional Confucianism: Sharing Mistakes or Self-Criticism in Public to People Is Both Moral Behavior and a Political Obligation on the Perspective of Mistake-Tolerant Democracy}

Modern Neo-Confucians have not done well in integrating Confucianism with democracy and science since Liang Shuming's initiated modern Neo-Confucianism. Especially for oversea Confucians who live and work in Western democratic institutions, they have completely exhausted the essence of Confucianism, but still could not achieve the mission. So the author argues that in order to realize China's century dream of "modern transformation of traditional Confucianism" or to build a bridge between Confucianism and "democracy and science", the other side of it should not be liberal democracy. Therefore, we have to achieve both the missions: to construct a more universal democratic theory than liberal theory or at least different from it, and then to reconstruct moral Confucianism based on the new democratic theory.

The key question is: What kind of democratic theory is likely to be more universal than liberal democracy? It is the most difficult and crucial step to reconstruct a new democratic theory, which should be so different from liberal democracy that Western scholars are likely reluctant to accept at first. Liberal democracy was ever regarded as universal value by most of Western states. Could we imagine that there does exist democratic theory than liberal democracy? So far, it can be called universality mainly including scientific methods and scientific philosophy. According to Joseph Needham's saying,

Universality and superiority are comforting conclusion for Westerners to reach about themselves. Yet there is a fallacy in it...The real universal factors are modern science and technology, together with the philosophies which made them possible. And it should be clearly understood that Europe did not give rise to "European" or "Western" science, but to universally valid science. (Needham, 1969, pp. 12-13) 
Karl Popper as a famous scientific philosopher put forward the development of knowledge: “... $\mathrm{P}_{1}-\mathrm{TT}-\mathrm{EE}-\mathrm{P}_{2} \ldots$.." (TT means trial theory; EE means error elimination) (Popper, 1979). So the method of trial and error is fundamental with universality for science. If we can integrate trial and error with democratic theories directly, then maybe we can construct a new democratic theory more universal than liberal democracy. Mistake-tolerant democracy is based on the assumption that the right to trial and error is an original right of people to understand, transform, and protect the world. Through the study on the "Thought Experiment" in the ignorant period of human beings, it is concluded that everyone has an equal right to trial and error, but different individual has different ability to try and err. The right to trial and error is regarded as an original right, and rights to life, liberty (in non-innovative fields), and property are subordinate rights. Mistake-tolerant democracy is defined as following,

In modern nation-state, people authorize their right to trial and error as an original right to the political elite by election, in order to obtain corresponding profit and subordinate rights, such as right to life, education, and criticism etc. In the process of managing state affairs, the political elites' right to trial and error should be protected by the law and perform their obligation of criticism by people, self-criticism in public to people and must ensure that mistakes can be effectively shared, corrected and searched at the systematic level and thus perfect the governmental organization itself. (Zhou, 2018, p. 51)

To practice mistake-tolerant democracy, the system of "non-party, one party, two parties or multiparty" can be implemented, and the way of democratization "two-party or multiparty system" that Western countries have initiated is not the only but main way. Mistake-tolerant democracy emphasizes four aspects: (1) People have the equal right to trial and error as an original right; (2) political elites' right to trial and error is granted by people; (3) political elites excise the right to trial and error for people; (4) political elites who have the right to trial and error are supervised by the people. Since mistake-tolerant democracy is more universal than liberal democracy or at least different from it, can the problem of modern transformation of traditional Confucianism be solved by it?

The original point of mistake-tolerant democracy is the state of nature, just like that of liberalism. In order to dialogue easily with liberalism, here the author puts forward the concept of mistake-tolerantism, the theoretical basis of which is the right to trial and error as an original right and mutual empowerment theory, compared with traditional liberal right theory "natural right theory and social contract theory". The difference between mistake-tolerantism and liberalism is: Liberalism starts from the premise that man is born knowing, because in the state of nature, human beings have the right to life, liberty, and property, and know the meaning of rights before they enter societies. John Rawls's theory of justice has similar background, because people standing behind the veil of ignorance have mastered basic knowledge of societies (Rawls, 1999). So the author regards that Rawls's theoretical point is similar to John Locke's state of nature in which people was born with knowledge (Locke, 1967). But mistake-tolerantism starts from the premise that man is born unknowing, which fits China’s tradition, because Confucius highlights man is not born with wisdom.

Mistake-tolerantism divides liberty into the right to trial and error as an original right in innovative fields and liberties as subordinate rights in non-innovative fields, which cannot be accepted in terms of the whole development of liberalism and liberal democracy up to now. Throughout its development, such as Thomas Hobbes (1996), John Locke (1967), Jean Jacques Rousseau (1924), Baron de Montesquieu (1900), Alexander Hamilton, James Madison, and John Jay (1982), Alexis de Tocqueville (1947), Thomas Paine (1993), John Mill (1978) as the representative of utilitarianism, John Dewey (1971) as the pragmatism representative, Joseph A. 
Schumpeter (1954) advocating electoral democracy, Robert A. Dahl (1971; 1989) as the theorist of polyarchal democracy, Jurgen Habermas (1996) developing deliberative democracy, John Rawls (1999) as the representative of the theory of justice, Hayek (2011) and Giovanni Sartori (1987), did not realize the important significance of the above differences in constructing democratic theory, so that Hobbes, Locke, and Rousseau etc. have not integrated the trial and error with the state of nature. Giovanni Sartori (1987, p. XIII) said, "Had no such trial-and-error scanning shaped the vocabulary of politics from Aristotle to, say, Tocqueville, today we would be nowhere, and certainly not even in sight of the democracies that we have been able to build". Giovanni Sartori emphasizes the importance of trial and error, but he does not expound the relationship between the right to trial and error with all other rights.

What will happen without the above discrimination? At the level of subordinate rights, liberty such as right to speech, cannot be transferred. If liberty in non-innovative fields were robbed, human beings would become a slave. But at the level of an original right, liberty in innovative fields which equals the right to trial and error can be transferred; in the meantime, people should be empowered corresponding rights by the one who gets the right to trial and error. Hayek criticized that people gave up their liberty to gain other advantages (Hayek, 2011). At the level of subordinate rights which cannot be granted, Hayek's ideas are right, but at the level of an original right, his idea is wrong, because we can give up or authorize the original right to trial and error to others, in order to gain profit and subordinate rights to supervise the political elites (Zhou, 2018). On the other hand, in the Bible, the method of trial and error became important, because Adam and Eve left the Garden of Eden and lived on the Earth. Environments are new and people need to try and err to understand the new world. However the way of spreading knowledge from one generation to another was destroyed by the flood and different languages in the Bible (Zhou, 2018). Especially people would not like to obey the God, so they want, by means of trial and error, to explore nature and social structures.

What's more, in autocratic societies, mistake-tolerantism still has strong explanatory power, i.e., the right to trial and error as an original right and mutual empowerment theory can generally explain all kinds of social phenomena, but liberalism cannot. Monarch and president elected by people solve a new problem with the same method of trial and error. They have the same power to solve the problem with trial and error, which can be called "the power to trial and error". The difference is that president's power to trial and error granted by people is a legitimate right, but monarch's power to trial and error not granted by people is not a legitimate one. The power to trial and error as an original right is controlled by minorities in autocratic societies, and people have the equal right to trial and error in democratic countries. The analysis mentioned above has shown the importance of "the state of nature" plus "trial and error". But liberal democracy is based on the liberalism, the premise of which is that man is born knowing. Therefore liberal democracy cannot help Chinese culture solve the problem of modern transformation of traditional Confucianism, or we can say there is no bridge between Confucianism and liberal democracy, because traditional Confucianism not affected by the Bible believes that man is not born knowing. Mistake-tolerant democracy based on mistake-tolerantism is consistent with China's tradition of "man is not born knowing", consistent with the Bible in essence, because the method of trial and error became more and more important when Adam and Eve left Eden. So the author thinks it is possible for us to solve the century problem easily.

It is worth mentioning that modern transformation of traditional Confucianism actually includes the above three sub-problems. Mistake-tolerant democracy is based on the philosophy of mistake-tolerantism, theoretical point of which is the state of nature integrated with scientific method of trial and error. Therefore, sub-problem 
2 and 3 mentioned above can be merged into one. It means that if we answer sub-problem 3 concerning building a bridge between Confucianism and democracy, then sub-problem 2 is answered in the meantime. As a matter of fact, modern Neo-Confucians such as Liang Shuming, Xiong Shili, and Mou Zongsan, also discussed sub-problem 2 and 3 together.

There are two key problems in the theory of mistake-tolerant democracy: The first is how to authorize people's right to trial and error to political elites; the second is how to empower corresponding rights and profits to people. Confucianism has not mentioned the right to trial and error, and in fact, its ideology did not mention the right from people, and do not criticize king's power from the heaven either and his power is not a legitimate right. From the beginning, Confucianism does not have any inclination to answer the first problem, so the author focuses on the second one. In feudal societies, a wise monarch would like to empower corresponding rights to people, but people have not authorized their rights to him. When people's rights were protected by law made by kings and their supporters, dynasties usually developed well. However, people's rights granted by kings were unstable, because kings' power was not authorized by people. If a king wanted to get back the rights he had authorized to people or abused his power, it was very difficult for people to protect themselves, except for overthrowing him.

From the perspective of mistake-tolerant democracy, people's right to criticism and political elites' obligation to self-criticism in public to people are the basic principles of the political system obeyed by political elites. How can mistake-tolerant democracy be associated with traditional Confucianism? In other words, how can Confucianism with the core of morality integrate with mistake-tolerant democracy? The question is whether elites' self-criticism in public to people can be regarded as moral activities. If self-criticism in public to people is the highest level of moral Confucianism, then the bridge does exist between Confucianism and mistake-tolerant democracy, even though it is not perfect. Specifically, in the field of morality, self-criticism in public to people is the highest level of morality; in political fields, the right to trial and error is the basic right of political elites, while rights to criticism by people, self-criticism in public to people and error correction are elites' obligations. Other rights such as the rights to education, supervision, and freedom in non-innovative fields are empowered and protected by political elites who are authorized by people through the law, which is called mutual empowerment theory. In view of this, we need to re-examine the core of moral Confucianism carefully.

In Confucianism, Confucius put benevolence (Ren) ${ }^{1}$ as the highest moral principle and standard; etiquette is the form of expression of benevolence; filial piety and fraternal duty are the moral foundation. He declares that his way has one theme running throughout, which consists of loyalty and reciprocity (Waston, 2007, pp. 33-34), and the doctrine of the Mean as the highest order, "The virtue embodied in the doctrine of the Mean is of the highest order” (Waston, 2007, p. 46). After Confucius, Confucianism was developed by Mencius, Xunzi, Dong Zhongshu in Han Dynasty and Neo-Confucian Zhu Xi in Song Dynasty. In Ming Dynasty and Qing Dynasty, Wang Fuzhi, Huang Zongxi, and Yan Yuan etc. criticized and re-interpreted Confucianism. After May Fourth Movement in 1919, Confucius’s ethics obtained modern interpretation by modern Neo-Confucians and was preserved and handed down from one generation to another. But there are no scholars who have attempted to understand Confucius's ethics systematically through the angle of sharing mistakes or

1 Ren can be translated into "benevolence”, “altruism”, “goodness”, or "humaneness” etc., http://www.acmuller.net/con-dao/analects.html. 2018-03-29. 
self-criticism in public to people. Then, is there any connection between a gentleman as a moral model and an obligation of self-criticism in public to people in Confucianism? The answer is "Yes".

Confucians have paid great attention to self-reflection or self-criticism in private, and found their own mistakes. Master Zeng said,

Each day I examine myself on three matters. In making plans for others, am I being loyal to them? In my dealing with friends, am I being trustworthy? Am I passing on to others what I have not carefully thought about myself? (Waston, 2007, p. 16)

Zeng found his own mistakes by reflection, "If you make mistakes, don’t be afraid to correct them” (Waston, 2007, p. 63). It is better if we can do like Yanhui, Confucius's loving-learning student, "Never repeated his mistakes" (Waston, 2007, p. 42). How does the gentleman (or the noble man) as a moral model deal with his mistakes? Zigong Said, “The gentleman's errors are like eclipses of the sun or moon. His error can be seen by all, and when he corrects them, all look up in admiration” (Waston, 2007, p. 136). The problem is why people can know gentleman's errors so clearly. There is no explanation in the Analects directly, but we can assume that if he does not have spirit of sharing mistakes or criticizing himself in public, or if he would like to hide his mistakes from his students, they could not be like eclipses of the sun or moon. This hypothesis of sharing mistake or self-criticism in public to people is reasonable, because we can find evidences in the Analects.

Although Confucius has not mentioned clearly that human beings can learn from mistakes, but he would like to show how he obtained knowledge. For instance, when Confucius talked about the relationship of "learning and thought”, he said, "Learning without thought is pointless. Thought without learning is dangerous" (Waston, 2007, p. 21). While Confucius taught his students, he could just tell them the above aphorism without any explanation, and look like a Saint with absolute authority, just like he was born with wisdom. Actually, Confucius did not do that. Before he concluded, Confucius told his students his trial, "Once I went all day without eating and all night without sleeping in order to think. It was no use--better to study” (Waston, 2007, p. 110). When Confucius told his students that "Thought without learning is dangerous", he usually asks himself, "Have not practiced what I have preached?” (Muller, 2018). So he should practice firstly, what will happen if he just thinks without learning, as called the process of trial and error. Confucius would like to tell his students how he tried and erred, and finally found the truth. Did Confucius practice the situation of "Learning without thought"? In the Analects, there is no mentioning of it, but we can reason that Confucius has practiced it, because it is easy to practice and he would like to ask himself "Have not practiced what I have preached?" According to analyses above, Confucius has the spirit of sharing mistakes or self-criticism in public which means that he is willing to disclose his activities of trial and error to his students.

According to Zigong's definition of the gentleman or noble man, whom a respected emperor should court, gentlemen as a moral model should have two characters of morality and knowledge: The spirit of sharing mistakes or self-criticism in public to people is basic requirement of gentlemen. If he has no such spirit, it is impossible for his errors to be like eclipses of the sun or moon. If he had tried to hide his mistakes, his error could have not been seen by all. Confucians emphasized reflection (Waston, 2007, p. 16), and tried not to repeat their own mistakes (Waston, 2007, p. 42), which is called self-discipline. Furthermore, they are willing to share their mistakes in public in order to let others supervise themselves, which is called heteronomy. Self-discipline and heteronomy make Confucians' morality perfect. On the other hand, the gentleman should have plenty of knowledge, and have an ability to correct their own mistakes. If he shared the same mistakes 
again and again, the spirit of sharing mistakes would be meaningless. In the Analects, there is no any direct guidance to ask teachers or leaders to share their mistakes with students or people, but actually Confucius practiced the spirit of sharing mistakes, like the eclipse of the sun and moon to be seen by all, when he explored knowledge.

Therefore, sharing mistakes or self-criticism in public to people is not only the moral requirement of gentlemen, but also the learning resource for others, for learning from mistakes is the fundamental method of human beings, not concerning any nations or races. In China's traditional Confucianism, to gain knowledge is related to trial and error closely. Confucius as the master was not born with wisdom (Waston, 2007, p. 50), and did not pretend to know everything. He was a lover of antiquity, and has diligently worked to acquire understanding (Waston, 2007, p. 50). What happened to a person who loved antique knowledge and studied it hard? As a result, his life would be accompanied by errors, and he also estimated when he could decrease his big mistakes, "Give me a few more years - if I have fifty years to study the Changes, then perhaps I, too, can avoid any great errors” (Waston, 2007, p. 50). Confucius does not dare to say he could avoid all kinds of errors, just only decrease great errors. Unfortunately, as far as Confucian morality studied systematically is concerned, most of Chinese scholars have focused on the "Benevolent love, righteousness, propriety, wisdom, and faithfulness", which have been replaced or marginalized by "Freedom, Equality, Fraternity, and Human Rights" of modern societies.

Mistake-tolerant democracy emphasizes that political elites perform their obligations of criticism by people, self-criticism in public to people and must ensure that mistakes can be effectively shared, corrected, and searched at the systematic level. Politician's self-criticism in public to people that liberal democracy does not mention is very important for mistake-tolerant democracy. According to analysis mentioned above, the bridge between Confucianism and democracy does exist: One side of the bridge is that sharing mistakes or self-criticism in public to people in traditional Confucianism is regarded as a moral practice; the other one of it is that self-criticism in public to people is political elites' obligations. Moral practices in Confucianism have become politician's obligation in mistake-tolerant democracy, which means that it can at least partially help us fulfill the century problem of modern transformation of traditional Confucianism. Furthermore, the gentleman who shares his mistakes with students or people indeed should accept others' criticism willingly. Mistake-tolerant democracy is regarded as new Outer Kingliness rather than liberal democracy, and sharing mistakes or self-criticism in public to people is accepted as New Inner Sageliness besides "Benevolent love, righteousness, propriety, wisdom, and faithfulness”, as shown in Figure 2.

It should be noted that liberal democracy does not recognize that sharing mistakes or self-criticism in public to people plays a double role of politician's obligation and moral practices. In view of sharing mistakes with people as the highest level of morality, few Western politicians could practice it. Therefore, systematic designers cannot rely too much on the individual initiative conduct of self-criticism in public, but as far as possible through the system construction, let people criticize and supervise the government, because the ultimate source of power is granted by the people.

Confucianism highlights personal moral practices, and the highest level of it is to become a Saint like Confucius. What are Saint's characteristics? He should have the spirit of sharing mistakes or self-criticism in public to people and an ability to correct mistakes according to Zigong's description (Waston, 2007, p. 136). Self-criticism in public to people is originated from one's own conscience, because the human being can learn from mistakes and sharing mistakes can help others save time, energy, and even life. We can imagine that if 
everyone kept his mistakes secretly and did not share them with his members in a community, the other would have to repeat the same mistakes without any progress. Such a society without sharing mistakes or self-criticism in public to people is in danger and unstable. In China's feudal societies, there are a lot of farmer's riots to overthrow a dynasty, because they regarded that monarch's behavior are wrong and would not like to correct them. If the monarch practiced self-criticism in public to people and corrected his own mistakes, it is not necessary for farmers to overthrow it at the expense of lives. Although self-criticism in public to people mentioned in Confucianism focused on the problems in people's lives not concerning science, the spirit of it in social and material sciences is the same.

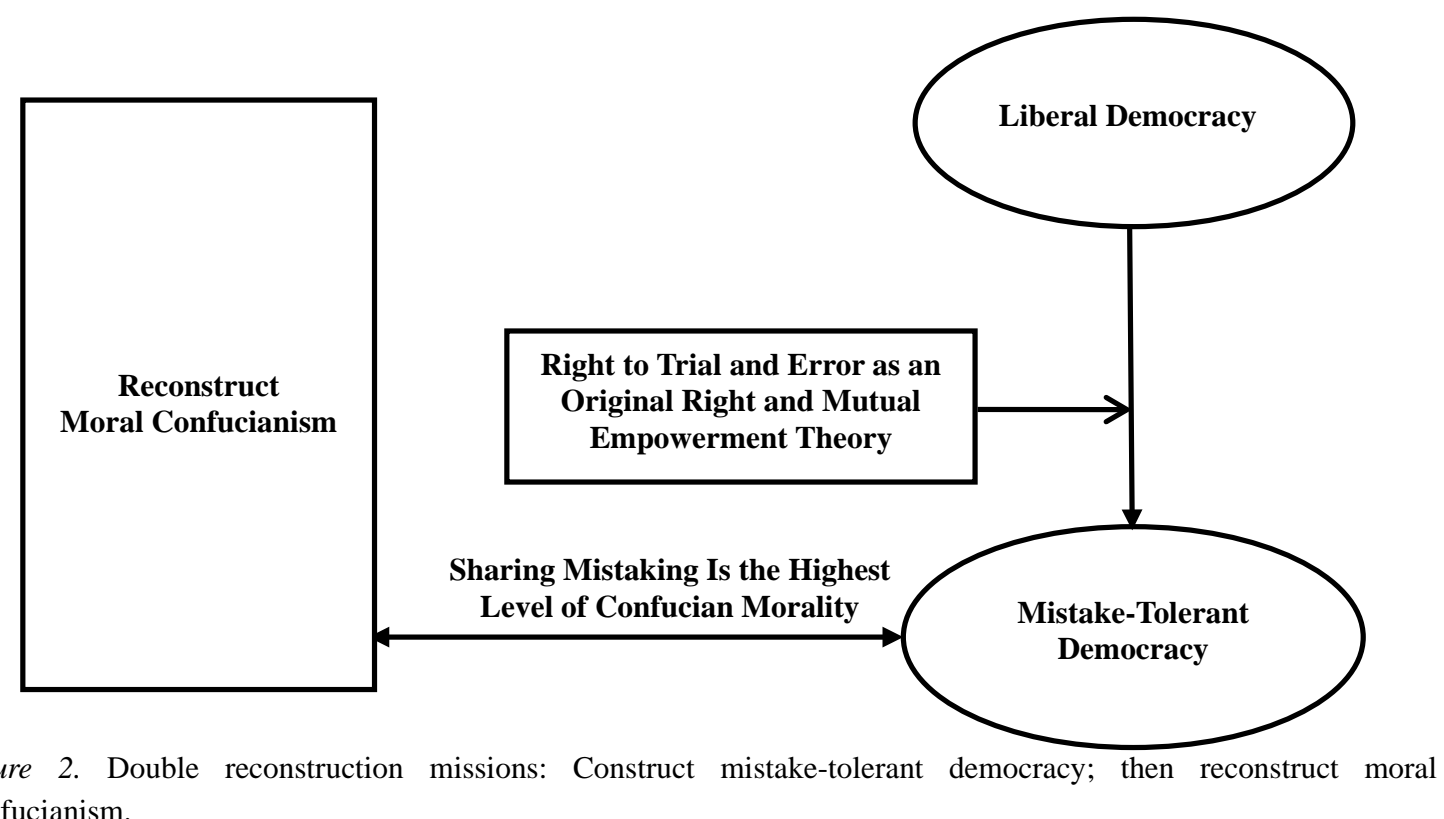

Confucianism.

Generally speaking, there does exist an incomplete bridge between traditional Confucianism and mistake-tolerant democracy. According to the relationship between right and obligation, a politician who has obligations of criticism by people, self-criticism in public to people, and mistakes corrected should have corresponding right, the right to trial and error, which should be protected by law. From the angle of mistake-tolerant democracy, modern transformation of traditional Confucianism can achieve the second half in the field of obligations, but Confucianism does not mention the first half about the modern core of democracy that leader's rights are authorized by people. So Confucianism has to learn from Western values. In a society, criteria of what is right or wrong are controlled by people who have the right to trial and error. In feudal societies where monarch's power was given by the heaven, people had no right to participate in the formulation of criteria of what is right or wrong effectively, and they have no right to supervise the government. Secondly, what could people do if an emperor made mistakes and was unwilling to engage in criticism by people and self-criticism in public to people, and reluctant to correct them, and his mistakes accumulated more and more? China's long feudal history has shown that dynasties have never been able to find a peaceful and perpetual solution to the problem. Due to the lack of effective institutional guarantee, people cannot participate in correcting mistakes made by emperors in legal ways. When irreconcilable contradictions accumulated, the only way to correct their mistakes is to overthrow them at the cost of people's life through violent revolution. The 
cycle happened again and again in China. The only way to solve the Cycling is to strengthen democracy. In 1945, Huang Yanpei asked Mao Zedong how the communist party of China can solve the Cycling, i.e.,

The rise of something may be fast, but its downfall is equally swift...Throughout history, there are various examples: a ruler ignores state affairs and eunuchs use the opportunity to seize power; a good system of governance ceases to function after the person who initiated it dies; people who lust for glory but end up in humiliation. None has managed to break out of this cycle. (The Cycle Conversation, 2018)

Mao Zedong answered,

We've already discovered a new path. We can break out of this cycle. This new path belongs to the people. The government will not become complacent only if it is under the supervision of the people. If everyone takes responsibility, a good system of governance will prevail. (The Cycle Conversation, 2018)

Mao Zedong thought democracy was the best choice for solving Chinese "Cycle”, which means that supreme leader's power is authorized by people, and people supervise their leaders through the state system and mechanism to avoid the failure of government. Therefore, in order to fully integrate traditional Confucianism with modern democracy, we need to change from the people-oriented thought of "being the master of the people" to the democratic thought of "people is the master".

It needs to be explained that based on mistake-tolerant democracy, modern transformation of traditional Confucianism has been completed partly, which is to say, the unification of three Traditions proposed by Mou Zongsan has been finished with new meaning. In mistake-tolerant democracy, traditional moral value refers to the theory of Confucius and Mencius's mind, and sharing mistake or self-criticism in public to people is regarded as the highest moral criterion; the tradition of knowledge is concerning science. Science is a reasonable activity which explores nature and human society by trial and error. Confucianism argues that human beings can learn from their mistakes, consistent with scientific method of trial and error. The gentleman would like to share his mistakes with people in order to let others supervise him and learn from his mistakes; traditional political value is guided to mistake-tolerant democracy. Mistake-tolerant democracy is constructed on the right to trial and error as an original right, which is originated from scientific method of trial and error. So to practice mistake-tolerant democracy is to practice scientific method. So far, modern transformation of traditional Confucianism has been preliminarily solved. The above analysis has shown that unification of three Traditions has been fulfilled.

\section{Conclusion}

Why could modern Neo-Confucians not achieve the century mission? There are a series of predicaments that they have to climb over. The first one is to understand such a moral activity: sharing mistakes or self-criticism in public to people. Modern Neo-Confucians' representatives, such as Liang Shuming, Xiong Shili, and Mou Zongsan, developed moral Confucianism, but they have not illustrated that self-criticism in public to people is the highest moral activity or moral core in their moral theories systematically. The second is that self-criticism in public to people is regarded as a very important political obligation. From the relationship between right and obligation, political elites with the obligation of sharing mistakes or self-criticism in public to people should have the corresponding rights, the right to trial and error. The third is what the relationship is between "the right to trial and error" and the right to life, liberty, and property etc. Mistake-tolerantism is based on the new right paradigm of "the right to trial and error as an original right and mutual empowerment theory". 
The right to liberty is divided into "the right to trial and error as an original right" in innovative fields and "subordinate liberties" in non-innovative ones, which is totally different from liberalism. If China’s scholars accepted traditional liberalism, the new right paradigm would be rejected; therefore, it is impossible for them to construct a new democratic theory, mistake-tolerant democracy based on mistake-tolerantism, which is the fourth and the most difficult. The fifth is to build a bridge between Confucianism and mistake-tolerant democracy, which is likely the easiest predicament. When the above five were climbed over, it is very obvious for the defects of liberal democracy that confession in religion is far away from political activities. The two defects of liberalism mentioned above, misunderstanding of liberty and expulsion of confession as the spirit of religion, have existed for at least more than 300 years since John Locke developed liberalism in 1689 (Locke, 1967), but Western democratic theories have not realized them. That is why Western political activities need foreign cultures to reflect their own practices rather than declare their own theory of liberal democracy universal, because their political activities are not perfect, particularly expelling confession from democratic theory just like throwing the baby out with the bathwater.

When an American president makes his oath to his country, he puts his left hand on the Bible, but actually he is reluctant to perform the obligation of sharing mistakes or self-criticism in public to people in public affairs. On the contrary, Algerian president Abdelaziz Bouteflika criticized himself on TV for youth problem. Some of Algerian people said angrily to him that if you made mistakes please leave your position. Professor Ghiat Boufelia in Oran university of Algeria said to me, "I respect our president further, because he said he was wrong. To make mistakes is human”. Liberal democracy is popular in Algeria, but its defect has not been corrected, so President Abdelaziz Bouteflika's moral behavior cannot be supported by Western democratic theories. ${ }^{2}$ But mistake-tolerant democracy can support his behavior and accept that he just performed his obligation and showed his noble morality.

During the development of modern Neo-Confucianism for nearly 100 years, liberal democracy is the main reference system. Therefore, no matter how modern Neo-Confucians have tried their best to solve the century problem, traditional Confucianism has never been able to demonstrate its ability to survive in the field of modern democracy and science. In the times of Liang Shuming, Xiong Shili, Mou Zongsan, Tang Junyi, and $\mathrm{Xu}$ Fuguan etc. as modern Neo-Confucians, history does not give them a good opportunity to doubt the universality of liberal democracy, so that these outstanding modern Neo-Confucians have exhausted the essence of Confucianism, and still couldn't build a bridge between Confucianism and "modern democracy and science”. A few modern Neo-Confucians such as Liang Shuming have realized that liberal democracy is a special local product of Western culture (He, 2001, p. 35). However, they failed to construct a new democratic theory conforming to Chinese tradition.

Furthermore, whether Confucianism as China's cultural core in the past 200 years can be integrated with modern democracy and science or not is related to China's future of civilization and politics, even related to the whole future of Eastern Asian Confucian culture. When China is to rejuvenate itself, she should learn from both traditional culture and Western value. But without universal value, her ideology cannot be accepted by the world. Therefore, modern transformation of traditional Confucianism is a major problem to be solved. The question is whether this theory has a practical soil, and whether it was permanently removed from institutional

\footnotetext{
2 In 2010, I visited Oran university of Algeria. Professor Ghiat Boufelia told me the above affair. I also asked several other staffs about it, and they confirmed their president's activity of self-criticism on TV, when many young guys had no jobs and held a demonstration. Unfortunately, I have not found the related video.
} 
arrangements just like a "modern ghost?" (Yu, 1998, p. 233). Theoretical vitality lies in practice, and that of liberal democracy is not simply a theoretical concept. As Frederick Watkins pointed out, constitutional democracy as the practice of freedom movement was not the product of theoretical considerations but of practical experience in terms of its emergence at the beginning. However, the reason why constitutional democracy can continue to evolve and develop is that it is supported by liberal democratic theory (Watkins, 1967). Similarly, the maturity of mistake-tolerant democratic theory depends largely on the response and exploration in practice besides theoretical construction. Before mistake-tolerant democracy was put forward, mistake-tolerant mechanism was practiced widely in China. On July 1st 2006, The Ordinance of Trial and Error was enacted in Shenzhen City. Since then, mistake-tolerant mechanism that protects political elites' right to trial and error and empowers corresponding rights to people to supervise them spreads all over the country, as required by mistake-tolerant democracy (Zhou, 2018). Mistake-tolerant mechanism is consistent with Confucian ideas that recognize even the gentleman makes mistakes, and allow people to learn from his own mistakes. Obviously, it is advisable that China, in the realization of democracy, turns to mistake-tolerant democracy as an alternative path to success in the future.

Liberalism does not accept the right to be wrong as an original right, so it does not realize that democracy and autocracy are two different types of fruits on the same tree of the right to trial and error as an original right. The difference between them is that leader's power to trial and error in democratic countries is authorized by people, while it, in an autocratic country, is not authorized by people. The common characteristics between them are that leaders must consider how to exercise the power to trial and error properly. In principle, in any feudal society, as long as the wise leader exercised the power to trial and error by a reasonable way to make the country prosper, as accepted by people, then its institution and political culture is worthy of reference and inheritance in some parts. In China's feudal history, many wise monarchs whose power was not authorized by people exercised the power to trial and error in a reasonable way, which can still provide reference for the practice of democracy with Chinese characteristics, such as "the political system with a special minster whose duty is to criticize monarchs" (Qian, 2001, p. 102).

The construction of democratic theories with Chinese characteristics should inherit fine traditions in feudal societies with Chinese characteristics and absorb the essence of Western democracy. However, in reality, many of China's conscientious thinkers impacted by Western ideas, have not only failed to understand our own traditions, but hastily abandoned and spit on them. As a result, the relationship between Rescript of Penitence and modern democracy has long been completely ignored. Rescript of Penitence is China's unique cultural phenomenon in the long feudal history. It is a statement submitted by Chinese emperors to the heaven, and of self-criticism in public to people (Hou, 2013). Mistake-tolerance democracy can achieve modern transformation of traditional Confucianism partly and Rescript of Penitence as a democratic resource with Chinese characteristic has been in practice for over 2,000 years. According to Xiao Han's statistics, from 179 BC when Chinese monarch Liu Che formerly issued the first Rescript of Penitence to 1916 AD when Chinese last monarch Yuan Shikai issued the last one, there are 264 texts of Rescript of Penitence issued by 89 different emperors. The time span is 2,095 years, with an average of one Rescript issued in eight years (Xiao, 2008). But China has to learn democratic practice from the West, just like the West to learn that from ancient Greek. Rescript of Penitence is a unique Confucian democratic resource in China. From the development process of Rescript of Penitence, we can see that although it did not form institutional text in most dynasties, the monarchs would like to issue it when their legitimacy was in peril. It became restriction to monarch's power from 
morality. From societies in which the divine right of kings dominated to a modern democratic state, the legitimacy of Rescript of Penitence has been changed, but they, as the self-criticism-in-public texts, still have modern significance.

To build a bridge between Confucianism and modern democracy and science, the research path should be “from New Outer Kingliness to New Inner Sageliness” rather than “from Inner Sageliness to Outer Kingliness". That is to complete double reconstruction missions: (1) New Outer Kingliness: to rebuild democratic theory which is more universal than liberal democracy. In this article, it is mistake-tolerant democracy; (2) New Inner Sageliness: to rebuild moral Confucianism based on mistake-tolerant democracy. The moral activities of Confucianism have reached a high level, which emphasizes political elites' obligation of self-criticism in public to people, as is the shortcoming of liberal democracy, because of its separation from religion. So we can conclude that liberal democracy is not universal and mistake-tolerant democracy has overcome the defects of liberal democracy, making the latter more universal than the former. Jiang Qing said, "Confucian pursuit is higher than political ideals of Western democracy. New external King accepted by modern Neo-Confucianism should include both ingredients of Western democracy and Confucian political ideals, rather than keeping up with Western liberal democracy without China's ideas” (Jiang, 1991, p. 162-163). The author agrees with Jiang's opinion, and thinks Joseph Needham has more insight, because he regards that the emperor on earth was both priest and king, i.e., the unitary head of church and state (Needham, 1969, p. 70). Mistake-tolerant democracy is such a kind of democracy required by Joseph Needham.

\section{References}

Ackerly, B. A. (2005). Is liberalism the only way toward democracy? Confucianism and democracy. Political Theory, 33(4), 547-576.

Chang, Y.-S. (2003). Mutual help and democracy in Korea. In D. A. Bell and C. B. Hahm (Eds.), Confucianism for the modern world (pp. 90-123). New York: Cambridge University Press.

Dahl, R. A. (1971). Polyarchy: Participation and opposition. New Haven: Yale University Press.

Dahl, R. A. (1989). Democracy and its critics. New Haven: Yale University Press.

Dewey, J. (1971). Democracy and education. New York: The Macmillan Company.

Du, W. M. (2005). Dialogue and creation. Guilin: Guangxi Normal University Press.

Dumenil, G., \& Levy, D. (2004). Capital resurgent: Roots of the neoliberal revolution. Cambridge, MA: Harvard University Press.

Gu, H. L. (2018). Liang Shuming's concept of democracy. Retrieved from http://www.doc88.com/p-0496419930370.html

Guo, J. N. (1997). Predicament of modern transformation of traditional Confucianism. Open Times, 3, 70-74.

Habermas, J. (1996). Between facts and norms: Contributions to a discourse theory of law and democracy. (W. Rehg, Trans.). Cambridge: The MIT Press.

Hall, D. L., \& Ames, R. T. (1999). The democracy of the dead: Dewey, Confucius, and the hope for democracy in China. Peru, Illinois: Open Court Publishing Company.

Hamilton, A., Madison, J., \& Jay, J. (1982). The Federalist papers. New York: Bantam Books.

Hayek, F. A. (2011). The constitution of liberty. Chicago: University of Chicago Press.

He, L. (1988). Culture and life. Beijing: The Commercial Press.

He, X. Q. (2001). Confucianism and modern democracy: Research on contemporary Neo-Confucian political philosophy. Beijing: China Social Sciences Press.

Hobbes, T. (1996). Leviathan. Oxford: Oxford University Press.

Hou, Y. J. (2013). Ancient and modern Rescript of Penitence. Yan Huang Chun Qiu, 5, 83-85.

Jiang, Q. (1991). From moral Confucianism to political Confucianism: Another developmental direction of contemporary Neo-Confucianism. In Committee of Contemporary Neo-Confucianism Anthology (Ed.), Anthology of contemporary Neo-Confucianism (pp. 162-163). Taipei: Wenjin Press. 
Liang, S. M. (1989). Complete works of Liang Shuming, Volume II. Jinan: Shandong People’s Publishing House. Liang, S. M. (1999). Eastern and western cultures and their philosophies. Beijing: The Commercial Press.

Lin, A. W. (2001). From Outer Kingliness to Inner Sageliness: Social justice as Confucian core-New thinking on Post-Neo-Confucianism. Zhejiang Social Sciences, 22(2), 1-7.

Locke, J. (1967). Two treatises of government. Cambridge: Cambridge University Press.

Mill, J. S. (1978). On liberty. Indianapolis: Hackett Publishing Company, Inc.

Montesquieu, B. (1900). The spirit of law. New York: The Colonial Press.

Mou, Z. S. (2006). Zhengdao and Zhidao. Guilin: Guangxi Normal University Press.

Mou, Z. S. (2010). Moral idealism. Changchun: Jilin Publishing Group Co. Ltd.

Muller, A. C. (Trans.). (2018). The analects of Confucius. Retrieved from http://www.acmuller.net/con-dao/analects.html

Needham, J. (1969). Within the four seas: The dialogue of east and west. London: George Allen \& Unwin Ltd.

Paine, T. (1993). Common sense. Shenyang: Liaoning People’s Publishing House.

Popper, K. (1979). Objective knowledge: An evolutionary approach. Oxford: Clarendon Press.

Qian, M. (2001). New perspectives on national history. Beijing: SDX Joint Publishing Company.

Rawls, J. (1999). A theory of justice (Revised ed.). Cambridge, MA: Harvard University Press.

Ren, J. T. (2018). Accredit to Neisheng (Inner Sageliness) what belongs to Neisheng and accredit to Waiwang (Outer Kingliness) what belongs to Waiwang: The modern breakthrough of Confucianism. Journal of Renmin University of China, 1, 92.

Rousseau, J. J. (1924). The social contract. London: G. Allen \& Unwin.

Saad-Filho, A., \& Johnson, D. (2005). Neoliberalism: A critical reader. London: Pluto Press Ltd.

Sartori, G. (1987). The theory of democracy revisited. New Jersey: Chatham House Publishers, Inc.

Schumpeter, J. A. (1954). Capitalism, socialism, and democracy. London: George Allen \& Unwin.

Song, Z. M. (2007). Achievement. Predicament and trend of moral Confucianism. Frontiers of Philosophy in China, 2(4), 503-516.

Tan, S.-H. (2004). Confucian democracy: A Deweyan reconstruction. Albany: State University of New York Press.

Tang, J. Y. (2005). Cultural consciousness and moral reason. Beijing: China Social Sciences Press.

Tang, Z. J. (Ed.). (1981). Political theory of Kang Youwei. Beijing: Zhonghua Book Company.

The Cycle Conversation. (2018). Retrieved from https://en.wikipedia.org/wiki/Huang_Yanpei

Tocqueville, A. (1947). Democracy in America. (H. Reeve, Trans.). London: Oxford University Press.

Waston, B. (Trans.). (2007). The analects of Confucius. New York: Columbia University Press.

Watkins, F. (1967). The political tradition of the west: A study in the development of modern liberalism. Cambridge, Mass.: Harvard University Press.

Xiao, H. (2008). Rescript of Penitence with China's ancient legitimacy of politics. Retrieved from http://article.chinalawinfo.com/article_print.asp?articleid=38687

Xiong, S. L. (1985). New doctrine of consciousness. Beijing: Zhonghua Book Company.

Ye, R. C. (2005). Rethinking Confucianism and democracy under global capitalism. Retrieved from https://max.book118.com/html/2017/0913/133779231.shtm

Yu, Y. S. (1998). Discussion of modern Neo-Confucianism. Shanghai: Shanghai People’s Publishing House.

Zhang, J. M. (2006). The history of Neo-Confucian thought. Beijing: China Renmin University Press.

Zhang, Z. D. (1900). China's only hope. New York: Fleming H. Revell Company.

Zhou, Z. F. (2018). The construction of mistake-tolerant democracy based on the practical right "right to trial and error". International Relations and Diplomacy, 6(1), 40-53. 